\title{
Cassia leptophylla, Gold Medallion Tree ${ }^{1}$
}

\author{
Michael G. Andreu, Melissa H. Friedman, and Robert J. Northrop ${ }^{2}$
}

\section{Family}

Fabaceae or Leguminosae, bean family

\section{Genus}

Cassia comes from the ancient Hebrew word "quetsioth," first used by Dioscorides, a physician in Ancient Greece (40-90 AD). Linnaeus, also known as the father of taxonomy, was the first to use Cassia to signify members of this genus.

\section{Species}

The species name leptophylla is a combination of the Greek words lepto meaning "fine or slender" and phylla meaning "leaves," which together mean "slender leaves."

\section{Common Name}

\section{Gold / Golden medallion tree}

The names "gold medallion tree" or "golden medallion tree" refer to the bright yellow flowers that appear in spherical clusters thought to resemble "medallions" around the outer canopy of the tree.

\section{Description}

This semi-deciduous tree is native to southern Brazil but grows well in subtropical regions of the United States, such as Florida, Texas, and Hawaii. This tree requires well-drained soil with little threat of freezing temperatures and should be grown in direct sunlight for full flowering

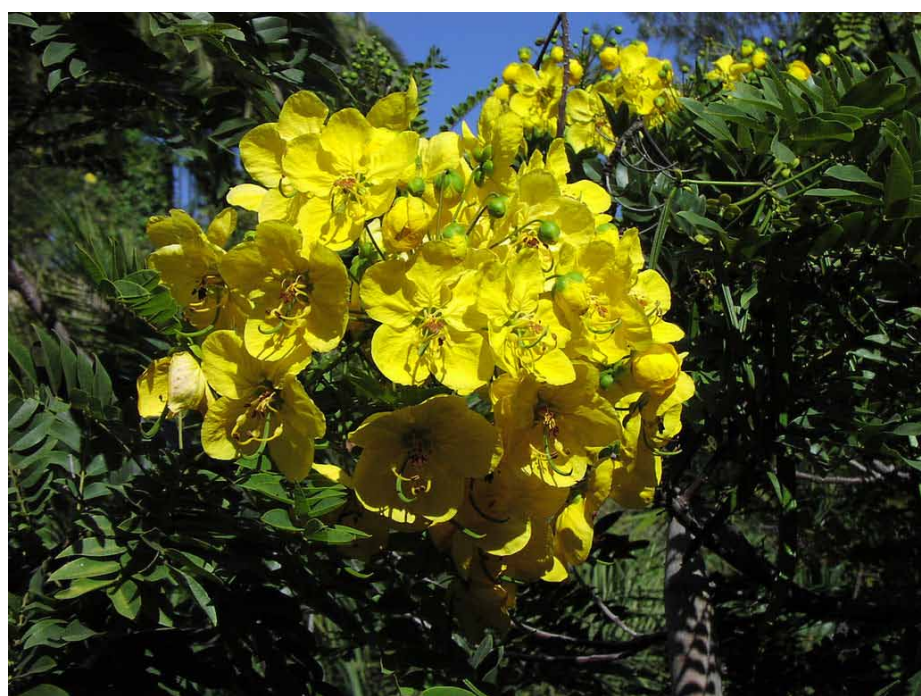

Figure 1. Gold medallion tree (Cassia leptophylla) in bloom Credits: Abraxas3d, CC BY-NC 2.0, http://flic.kr/p/ZmkC

potential. The gold medallion tree can reach heights of 30-40 feet with proper pruning. The dark green leaves are pinnately compound and alternately arranged. Leaves are made up of 8-12 oval- to spear-shaped leaflets that are generally $2-3$ inches long and $1 / 2$ inch wide. The bark and new woody stems are brown and smooth. Blooms are showy, yellow flowers that appear in spherical clusters around the canopy of the tree in the summer months, and fruits are foot-long dry pods.

\section{Allergen}

Members of the Cassia genus are moderately allergenic. Oil from the pods may cause skin irritation to some individuals.

1. This document is FOR295, one of a series of the School of Forest Resources and Conservation, Florida Cooperative Extension Service, Institute of Food and Agricultural Sciences, University of Florida. Original publication date July 2012. Visit the EDIS website at http://edis.ifas.ufl.edu.

2. Michael G. Andreu, associate professor; Melissa H. Friedman, research scientist; School of Forest Resources and Conservation; and Robert J. Northrop, Extension forester, Hillsborough County Extension; University of Florida, Gainesville, Florida 32611. 


\section{Applications}

\section{Horticultural}

The gold medallion tree is planted primarily as a shade tree or as a decorative specimen for the yard or street. Many people like this tree because of its fast growth rate and showy, bright yellow clusters of flowers that bloom in the summer months. This tree loses its leaves for a very short period each year, but leaves are quickly replaced. Pruning the tree to one main leading stem from which major branches are attached can help increase its strength and sturdiness against strong wind events. The golden medallion tree is also naturally pest resistant, and as long as it is grown in areas where the temperature does not drop below freezing, it is an easy tree to care for.

\section{Additional References}

Gilman, E. F. (1997). Trees for Urban and Suburban Landscapes. Albany, NY: Delmar Publishers.

Stebbins, M. K. (1999). Flowering Trees of Florida. Sarasota, FL: Pineapple Press.

University of Florida (2011). Landscape Plants: Cassia leptophyllia, Golden Medallion Tree. Retrieved from http:// hort.ufl.edu/woody/Pages/caslep/caslep.shtml. 